\title{
Effects of Common Viruses on Yield and Quality of Beauregard Sweetpotato in Louisiana
}

\author{
C. A. Clark and M. W. Hoy, Department of Plant Pathology \& Crop Physiology, Louisiana State University AgCenter, \\ Baton Rouge 70803-1720
}

\begin{abstract}
Clark, C. A., and Hoy, M. W. 2006. Effects of common viruses on yield and quality of Beauregard sweetpotato in Louisiana. Plant Dis. 90:83-88.

During cycles of vegetative propagation, sweetpotato accumulates viruses that are thought to contribute to decline in yield and quality of cultivars, but the effects of specific viruses, many of which have been described only recently, are unknown. Field plots planted with graft-inoculated plants of a virus-tested (VT) mericlone of cv. Beauregard were used to assess the effects of three common potyviruses, Sweet potato feathery mottle virus (SPFMV), Sweet potato virus $G$ (SPVG), and Ipomoea vein mosaic virus (IVMV); and a begomovirus, Sweet potato leaf curl virus (SPLCV), compared with natural inoculum introduced by grafting plants from farmers' stock. Single infections with SPFMV, SPVG, or IVMV did not significantly affect yield, whereas mixed infections with SPFMV + SPVG or SPFMV + SPVG + IVMV resulted in mean yields $14 \%$ less than the VT controls. Infection with SPLCV resulted in mean yields $26 \%$ less than the VT controls, despite not causing symptoms on the foliage. However, grafting with farmers' plants infected with an unknown mixture of pathogens resulted in mean yields 31 to $44 \%$ less than the VT controls. Infection with potyviruses resulted in storage roots with tan periderm and infection with SPLCV induced darker periderm than the rosy VT controls. Infection with the viruses known to occur commonly in the United States did not reproduce the magnitude of yield reduction that has been observed with naturally infected plants.
\end{abstract}

Additional keywords: cultivar decline, Ipomoea batatas

Sweetpotato, Ipomoea batatas (L.) Lam., is vegetatively propagated and therefore subject to accumulation of systemic pathogens in propagating material. Cultivar decline, a phenomenon in which yield, quality attributes, or both deteriorate over time after deployment of a new cultivar, has become a concern $(4,5,10)$. There has been speculation that this decline is the result of increasing frequency of mutations or the accumulation of pathogens in the planting stock (10). A number of pathogens can pass from one generation of sweetpotato production to the next on storage roots used for "seed"; however, with the exception of systemic pathogens, most are adequately controlled by integrated programs of sanitation, chemical control, and use of resistance (9). Virus symptoms are common on sweetpotato but, for many decades, there was little effort to control viruses in sweetpotato primarily because few viruses had been identified and the

Corresponding author: C. A. Clark

E-mail: cclark@agctr.lsu.edu

Approved for publication by the director of the Louisiana Agricultural Experiment Station as journal series no. $05-38-0271$.

Accepted for publication 24 August 2005.

DOI: 10.1094/PD-90-0083

(C) 2006 The American Phytopathological Society effect the specific viruses had on production had not been determined. Sweet potato feathery mottle virus (SPFMV) was first characterized and described in 1978 (24) and, until 1998, was the only virus reported from sweetpotato in the United States. During the past 5 years, much progress has been made on identifying viruses present in sweetpotato in the United States. Sweet potato leaf curl virus (SPLCV) was found in ornamental sweetpotato and some breeding lines but not in sweetpotato grown for commercial vegetable production (22). Samples collected from the southeastern United States and California were almost universally infected with SPFMV; however, in addition, many of the samples also were infected with two potyviruses that only recently have been identified: Sweet potato virus G (SPVG) and Ipomoea vein mosaic virus (IVMV) (33). Surveys conducted during 1999 to 2001 indicated that SPFMV was essentially universal, and SPVG and IVMV were common in sweetpotato plants from farmers' fields in the major sweetpotatoproducing states of the United States (C. A. Clark, unpublished data). SPLCV was found in only 1 of 200 samples from farmers' fields but was common in breeding lines and in purple-leafed ornamental sweetpotato. C-6, a putative carlavirus (32), also was found in the purple-leafed ornamental sweetpotato but not in any other samples.
Several approaches have been followed to try and determine the effects viruses have on sweetpotato yields. Yield and incidence of reinfection with viruses of virusindexed plants over time in the field has been used $(4,36)$, but it is not always possible to know what specific viruses were present or their contributions to reduction in yield. For severe diseases such as sweetpotato virus disease (SPVD), caused by the synergistic interaction of Sweet potato chlorotic stunt virus (SPCSV) and SPFMV, some workers have used plants with and without SPVD symptoms to compare yields $(15,25,27)$. Unfortunately, in some cases, the symptomless plants may have been infected with other viruses. Others have compared yields of virustested (VT) plants derived from meristemtip culture and virus indexing with naturally infected field-grown plants $(6,18,30)$. However, because mutations may occur during the meristem-tip culture process, it is difficult to know whether these plants have remained genetically comparable. To compensate for that problem, Carroll et al. (7) worked with multiple clones of cv. Beauregard and compared yield and quality of each of 12 original clones with a VT mericlone derived from the corresponding clone and found that the naturally infected clones yielded as little as $53 \%$ of the VT. They also found that VT differed from the infected parent clones in skin and internal flesh color of the storage roots. There have been few reports in which an attempt was made to study the effect of specific viruses. Milgram et al. (23) compared the effects of SPFMV and SPCSV (referred to by the synonym Sweet potato sunken vein virus) and found no effect of SPFMV on yield, a 50\% yield reduction for the combination of SPFMV and SPCSV, and SPCSV varying from no effect in the first year to a $30 \%$ reduction the second year. In Peru, Gutierrez et al. (14) found that SPFMV did not significantly affect yield of two cultivars, but that SPCSV significantly reduced yield and the combination of the two viruses caused SPVD and greater yield reduction.

Several U.S. states currently conduct programs aimed at providing propagating material to farmers that is derived from VT tissue cultures. However, recent studies suggest that the rate of reinfection with potyviruses of such material can be rapid $(4,10)$. This study was conducted to evaluate the effect of viruses that occur com- 
monly on sweetpotato in the United States on yield and quality of Beauregard, the predominant cultivar in U.S. sweetpotato production. Three potyviruses, the russet crack strain of SPFMV (SPFMV-RC), SPVG, and IVMV, and a begomovirus, SPLCV, were used. Preliminary results were reported previously (8).

\section{MATERIALS AND METHODS}

Pathogens. Isolate LSU-1 of SPVG initially was obtained from the sweetpotato cv. Beauregard grown in Louisiana that had been subjected to meristem-tip culture and was isolated by subsequent singleaphid-probe transmission (33). Isolate 95-2 of SPFMV was obtained from a Beauregard sweetpotato grown in New Mexico with russet crack-like symptoms and was isolated by single-aphid-probe transmission. This isolate induced russet crack on Jersey sweetpotato and reacted strongly with antisera to SPFMV-RC. Isolate LSU5 of IVMV initially was obtained from an O'Henry sweetpotato grown in Mississippi that had been subjected to meristem-tip culture and was isolated by subsequent transmissions from single local lesions on Chenopodium quinoa (33). Isolate SWFT1 of SPLCV was isolated from sweetpotato breeding clone $\mathrm{W}-285$ by single whitefly transmission (22). During 1996 to 1997 , virus-infected plants (as determined by indexing on I. setosa) from three farmers' fields were used as a source of natural virus inoculum. These plants were determined by enzyme-linked immunosorbent assay (ELISA) to be infected with SPFMV, but it is not known what other viruses or pathogens may have been present.

Plant production. All plants used in this study were derived from VT Beauregard mericlone B-63. This mericlone was produced in 1988 by meristem-tip culture, indexed for the presence of viruses by grafting three times in succession to the standard indicator host, I. setosa, and found to be apparently free of viruses. It has been maintained in tissue culture since that time by nodal propagation. Stock plants were established in a caged room in a greenhouse that excluded insect vectors and propagated by transplanting vine cuttings from October through March each year. To further reduce the possible transmission of viruses in the greenhouse, plants were treated weekly with insecticides, alternating between imidacloprid (Admire 2F; Bayer Corp., Kansas City, $\mathrm{MO}$ ) and avermectin (Avid 0.15EC; Novartis, Greensboro, NC). VT plants were inoculated with viruses by grafting scions from stems of plants confirmed to be infected with the appropriate viruses by nitrocellulose membrane-based (NCM)ELISA (32). Infected plants were increased in a separate greenhouse room by periodically transplanting 15 - to $30-\mathrm{cm}$-long terminal vine cuttings. The number of plants was increased further in the field by trans- planting vine cuttings and the rooted basal portions of the plants produced in the greenhouse into methyl bromidefumigated field beds in which granular imidacloprid (Merit 0.5G; Bayer Corp.), a systemic insecticide, had been incorporated at $90 \mathrm{~kg} / \mathrm{ha}$. Immediately after transplanting, the beds for the different virus treatments were separately covered with fabric row cover (Agribon+, PGI; Nonwovens, Dayton, NJ) suspended on wire hoops to exclude aphids and whiteflies.

Field plots. Land was prepared for planting by incorporating 8-24-24 fertilizer at $450 \mathrm{~kg} / \mathrm{ha}$ and EPTC herbicide (Eptam $7 \mathrm{E}$; Zeneca, Greensboro, NC) at 2.3 liters/ha, and by shaping rows into ridges approximately $30 \mathrm{~cm}$ tall and $1.2 \mathrm{~m}$ apart. Terminal vine cuttings approximately 30 $\mathrm{cm}$ long were cut from the field beds using flamed knives and used to plant all plots. The cuttings were planted $30 \mathrm{~cm}$ apart along the rows. Treatments were planted in a randomized complete block design. Two separate plantings, approximately a month apart, were made of each plot each year.

In plots comparing effects of viruses, the systemic insecticide imidacloprid (Merit $0.5 \mathrm{G}$ ) was incorporated at $90 \mathrm{~kg} / \mathrm{ha}$ in the soil throughout the field prior to planting. Plots consisted of a pair of such 20-plant subplots with a 20-plant guard row of VT on each side and four replications in 199697. During 1998 to 2003, five replications of single 20-plant plots were planted. Between each plot, three rows of soybean were planted in an effort to reduce spread of viruses between plots. Plants were watered immediately after transplanting and clomazone (Command 3ME; FMC Corp., Philadelphia) at 2.3 liters/ha was sprayed over the top for weed control. At harvest, sweetpotato storage roots were unearthed with a chain digger and sorted by hand into the following grades: US\#1 = roots 5.1 to $8.9 \mathrm{~cm}$ in diameter, 7.6 to $22.9 \mathrm{~cm}$ long; canners $=$ roots 2.5 to $5.1 \mathrm{~cm}$ in diameter, 5.1 to $17.8 \mathrm{~cm}$ in length; and jumbos = roots larger than the US\#1 but of marketable quality; and the weight of each grade was recorded. For some tests, five roots were selected at random following harvest from each replication of the VT control treatment. These roots were indexed to determine incidence of reinfection by grafting two small chips from each root to a seedling of I. setosa. The I. setosa seedlings were monitored for development of symptoms indicating that the scion was infected with viruses, and symptomatic plants were assayed by NCM-ELISA using antisera for SPFMV, SPVG, and IVMV.

Color assessment of storage roots from virus plots. On the day of harvest, US\#1-grade storage roots from each plot were processed through a washer and examined for symptoms, especially of russet crack, and perceptible differences in quality. Excluding roots with obvious abnormalities such as damage incurred in han- dling, three roots were selected randomly from each replication of each treatment. A Minolta spectrophotometer (model $\mathrm{cm}$ 3500d; Konica Minolta USA, Inc., Osaka, Japan) was used to determine Hunter color values of periderm and flesh of these roots. The parameters combined represent the spatial location (color) on a threedimensional sphere, where ' $a$ ' denotes redness (negative value) or greenness (positive value), 'b' denotes blueness (negative value) or yellowness (positive value), and ' $L$ ' denotes diffuse reflectance or lightness value $(0=$ black to $100=$ white) (16). Periderm color was measured on three separate locations on each root, after which the root was cut in cross section at the median and the color of the flesh inside the vascular ring was measured at three locations. The mean of values for the three locations and three roots from each replication was used for analysis.

Statistical analyses. The GLM procedure in SAS (ver. 9.1; SAS Institute Inc., Cary, NC) was used for analysis of variance. In most years, yields were significantly different and, thus, data were analyzed and are presented separately for the two planting dates. Where appropriate, Tukey's Studentized Range Test was used for separation of means.

\section{RESULTS}

Effects of naturally infected farmers' plants. The proportion of US\#1-grade roots did not differ among treatments and followed similar trends for total yields; therefore, only total yields are presented. In 1996-97, yield reductions were significantly less for plants graft inoculated with naturally infected plants from farmers' fields, ranging from 31 to $44 \%$ of the VT control (Table 1). However, in the same plots, SPFMV-RC did not significantly affect yields. Chlorotic ringspots and veinbanding, sometimes with purple margins, were observed during the season on older leaves of plants graft inoculated with naturally infected plants from farmers' fields, which are similar to symptoms commonly observed in farmers' fields. Plants infected with SPFMV-RC often were symptomless or showed only mild feathering along veins of older leaves.

Effects of SPLCV. The effects of SPLCV and SPLCV + SPFMV were evaluated during 1998 to 2000 . For those 3 years, yields of SPLCV plants were $74 \%$ of those of the VT controls, ranging from 62 to $108 \%$, whereas yields of SPLCV + SPFMV plants were $84 \%$ of the VT, ranging from 75 to $105 \%$ (Tables 2 and 3). Differences in yield were statistically significant only in 2000. In addition, roots from plants infected with SPLCV alone, or in combination with SPFMV, had a darker periderm and a lower Hunter $b$ value (Table 4) than any of the other treatments. Some storage roots infected with SPLCV also had shallow, longitudinal grooves that 
were not observed in any of the other treatments.

Effects of potyviruses. SPFMV-RC was evaluated in 16 replicated tests over 8 years, and total yields for plants infected with SPFMV-RC were not significantly different (mean $=96 \%$ of VT) in any of the tests from those of the VT control (Tables 1, 2, 3, and 5). The other two potyviruses, SPVG and IVMV, were not isolated and characterized until 2000, but were included in eight and six subsequent tests, respectively. Yields of plants infected with SPVG alone were $99 \%$ and for IVMV alone $94 \%$ of the VT control and were not significantly different from the control in any test (Tables 3 and 5). Overall, yields for plants infected with SPVG + SPFMV were $86 \%$ of the control, but differed significantly from the control only in the second test in 2000. Yields of plants infected with all three potyviruses were similar to those of plants infected with SPVG + SPFMV. The storage root periderm color of roots infected with potyviruses, especially those with multiple infections, was more tan in visual appearance and had lower Hunter a values as opposed to a rosy color for VT roots (Tables 4, 6, and 7). In some years, excess soil moisture just before harvest caused changes in skin color that were variable on roots and prevented accurate assessment of Hunter color values. Single infections with potyviruses did not significantly affect flesh color; however, in two tests, Hunter b values were lower for roots with multiple Potyvirus infection. Russet crack-like symptoms $(9,17)$ were observed only in 2002 on a low incidence of roots from plants infected with SPFMV-RC + SPVG + IVMV.

Incidence of reinfection. During 2000 to 2003, reinfection of the VT control ranged from 4 to $51 \%$ (mean $=18 \%)$. IVMV was not detected, SPVG was detected in 0 to $4 \%($ mean $=1 \%)$ of the VT roots, and SPFMV accounted for the remaining incidence of reinfection.

\section{DISCUSSION}

Grafting VT Beauregard with naturally infected sweetpotato caused substantial reductions in yield of Beauregard, with the yields of the grafted plants ranging from 56 to $69 \%$ of the VT. Carroll et al. (7) compared yields of 12 different clones of naturally infected Beauregard with yields of VT mericlones derived from each clone and found that yields of the infected clones were as low as $53 \%$ of the VT mericlones. Thus, it appears that the naturally occurring complex of graft-transmissible agents in sweetpotato in Louisiana can cause yield reductions of 30 to $50 \%$. Although there is no direct evidence to prove that viruses are responsible for the entire effect, the fact that the responsible agents are graft transmissible and eliminated by meristem-tip culture is consistent with viruses as the cause.
The yield reductions of 30 to $50 \%$ observed in U.S. sweetpotato production have stimulated the development of seed programs to produce VT seed; however, even greater yield reductions have been observed in countries where SPVD, a synergistic interaction between SPFMV and SPCSV, or similar virus complexes involving SPCSV, occur. Yield reductions attrib- uted to SPVD as great as $90 \%$ have been reported on Beauregard (1) with similar severity on other cultivars $(14,15,23$, 26,27). SPCSV, a whitefly-transmitted virus, has been confirmed from only one sample in the United States, an accession of $\mathrm{cv}$. White Bunch held in the United States Department of Agriculture Sweetpotato Germplasm Repository (31). Unfortu-

Table 1. Total yields of Beauregard sweetpotato grown from virus-tested (VT) plants compared with VT plants inoculated by grafting with either isolate 95-2 of a russet crack strain of Sweet potato feathery mottle virus (SPFMV-RC) or with plants randomly selected from field-grown plants that were infected with unknown, naturally occurring pathogens

\begin{tabular}{|c|c|c|c|c|c|c|}
\hline \multirow[b]{2}{*}{ Treatment } & \multicolumn{4}{|c|}{ Total yield (metric tons/ha)y } & \multirow[b]{2}{*}{ Mean } & \multirow[b]{2}{*}{ VT $(\%)$} \\
\hline & 1996-1 & 1996-2 & 1997-1 & 1997-2 & & \\
\hline VT & $35.6 \mathrm{a}$ & $27.1 \mathrm{a}$ & 44.3 & $19.9 \mathrm{a}$ & 31.7 & 100 \\
\hline SPFMV-RC & $31.0 \mathrm{ab}$ & $25.2 \mathrm{a}$ & 36.5 & $20.8 \mathrm{a}$ & 28.4 & 90 \\
\hline Farmer's plant A & $24.7 \mathrm{ab}$ & $15.4 \mathrm{ab}$ & 34.8 & $13.1 \mathrm{~b}$ & 22.0 & 69 \\
\hline Farmer's plant B & $21.4 \mathrm{~b}$ & $13.6 \mathrm{~b}$ & $\ldots$ & (10. & 17.5 & 56 \\
\hline Farmer's plant C & $19.9 \mathrm{~b}$ & $14.1 \mathrm{~b}$ & 31.3 & $10.4 \mathrm{~b}$ & 18.9 & 60 \\
\hline Source & \multicolumn{4}{|c|}{$\operatorname{Pr}>F^{\mathrm{z}}$} & & \\
\hline Treatment & 0.0065 & 0.0010 & 0.0732 & $<0.0001$ & & \\
\hline Rep & 0.5418 & 0.5506 & 0.8472 & 0.0033 & & \\
\hline
\end{tabular}

y Means in the same column followed by a common letter are not significantly different by Tukey's Studentized Range Test $(\alpha=0.05)$.

z Type I probability to exceed $F$ as determined using Proc GLM in SAS (ver. 9.0; SAS Institute, Cary, NC).

Table 2. Total yields of Beauregard sweetpotato grown from virus-tested (VT) plants compared with VT plants inoculated by grafting with either isolate 95-2 of a russet crack strain of Sweet potato feathery mottle virus (SPFMV-RC) or isolate SWFT-1 of Sweet potato leaf curl virus (SPLCV)

\begin{tabular}{llllr}
\hline & \multicolumn{4}{c}{ Total yield (metric tons/ha) } \\
\cline { 2 - 5 } Treatment & $\mathbf{1 9 9 8 - 1}$ & $\mathbf{1 9 9 8 - 2}$ & $\mathbf{1 9 9 9 - 1}$ & $\mathbf{1 9 9 9 - 2}$ \\
\hline VT & 26.1 & 35.6 & 19.2 & 19.3 \\
SPFMV-RC & 26.8 & 45.5 & 20.7 & 9.9 \\
SPLCV & 17.0 & 32.0 & 20.8 & 16.3 \\
SPLCV + SPFMV-RC & 19.5 & 37.4 & 15.9 & 16.3 \\
Source & & & $\boldsymbol{P r}>\boldsymbol{F}$ & \\
SPFMV-RC & 0.7560 & 0.5287 & 0.4702 & 0.1654 \\
SPLCV & 0.1419 & 0.0398 & 0.4755 & 0.6084 \\
SPFMV-RC $\times$ SPLCV & 0.8634 & 0.3912 & 0.1853 & 0.1654 \\
Rep & 0.9032 & 0.7773 & 0.7821 & 0.2749 \\
\hline
\end{tabular}

Table 3. Total yields of Beauregard sweetpotato grown from virus-tested (VT) plants compared with VT plants inoculated by grafting with either isolate 95-2 of a russet crack strain of Sweet potato feathery mottle virus (SPFMV-RC), isolate LSU-1 of Sweet potato virus G (SPVG), or isolate SWFT-1 of Sweet potato leaf curl virus (SPLCV)

\begin{tabular}{llc}
\hline & \multicolumn{2}{c}{ Total yield (metric tons/ha) } \\
\cline { 2 - 3 } Treatment & $\mathbf{2 0 0 0 - 1}$ & $\mathbf{2 0 0 0 - 2}$ \\
\hline VT & $32.5 \mathrm{ab}$ & $44.0 \mathrm{a}$ \\
SPFMV-RC & $32.9 \mathrm{a}$ & $36.7 \mathrm{ab}$ \\
SPVG & $32.2 \mathrm{ab}$ & $43.5 \mathrm{a}$ \\
SPVG + SPFMV-RC & $25.0 \mathrm{ab}$ & $25.5 \mathrm{~b}$ \\
SPLCV & $17.2 \mathrm{~b}$ & $26.6 \mathrm{~b}$ \\
SPLCV + SPFMV-RC & $24.9 \mathrm{~b}$ & $32.8 \mathrm{ab}$ \\
Source & & $\mathbf{P r}>\boldsymbol{F}^{\mathbf{z}}$ \\
SPFMV-RC & & \\
SPVG & 0.9139 & 0.0136 \\
SPVG $\times$ SPFMV-RC & 0.5553 & 0.8328 \\
SPLCV & 0.0715 & 0.0022 \\
SPFMV-RC $\times$ SPLCV & 0.0036 & 0.0013 \\
Rep & 0.2873 & 0.0286 \\
\hline
\end{tabular}

y Means in the same column followed by a common letter are not significantly different by Tukey's Studentized Range Test $(\alpha=0.05)$.

z Type I probability to exceed $F$ as determined using Proc GLM in SAS (ver. 9.0; SAS Institute, Cary, $\mathrm{NC})$. 
nately, the origins of White Bunch are unknown, making it difficult to ascertain how it may have become infected. The symptoms of SPVD are dramatic and have not been observed on sweetpotato in commercial production in the United States. However, during the 1940s to 1950 s, an episode of a disease called "Georgia Mosaic" erupted (3). This disease had symptoms similar to SPVD and was transmitted by whiteflies. An eradication program was conducted which fortunately coincided with a disappearance of whitefly populations in the affected areas, resulting in a report that the disease had been eradicated (13). This episode occurred before many of the tools of modern virology were developed and the identity of the causal agent is not known; however, it illustrates the potential for greater yield losses than presently occur, particularly given the increases in whitefly populations and whitefly-transmitted diseases in recent years (35).

Symptoms have not been observed on SPLCV-infected Beauregard (22; this study); however, SPLCV-infected plants produced yields that were $74 \%$ of that of the VT controls. Yields of plants coinfected with SPLCV and SPFMV were not significantly different from plants infected with SPLCV alone; however, in four of six tests, the coinfected plants had numerically greater yields. Given the mild symptoms in both singly infected and co-infected plants, this yield phenomenon is difficult to ex-

Table 4. Periderm and internal flesh color of Beauregard sweetpotato storage roots grown from either virus-tested (VT) plants or VT plants graft inoculated with isolate 95-2 of the russet crack strain of Sweet potato feathery mottle virus (SPFMV-RC), isolate LSU-1 of Sweet potato virus G (SPVG), or isolate SWFT-1 of Sweet potato leaf curl virus (SPLCV) in the first planting, 2000

\begin{tabular}{|c|c|c|c|c|c|c|}
\hline \multirow[b]{2}{*}{ Virus inoc. treatment } & \multicolumn{3}{|c|}{ Periderm } & \multicolumn{3}{|c|}{ Internal flesh } \\
\hline & Hunter L & Hunter a & Hunter b & Hunter L & Hunter a & Hunter $\mathbf{b}^{\mathbf{y}}$ \\
\hline VT control & 47.72 & 14.88 & 13.19 & 63.43 & 27.05 & 24.17 \\
\hline SPFMV-RC & 48.71 & 14.99 & 13.41 & 64.63 & 27.49 & 24.71 \\
\hline SPVG & 49.01 & 14.39 & 13.56 & 64.36 & 28.50 & $24.96^{*}$ \\
\hline SPVG + SPFMV-RC & 49.43 & 14.90 & 13.75 & 63.31 & 27.86 & 24.55 \\
\hline SPLCV & 46.80 & 14.98 & 12.33 & 64.04 & 28.61 & $25.34 *$ \\
\hline SPLCV + SPFMV-RC & 46.56 & 15.28 & 12.18 & 64.62 & 28.47 & $25.34 *$ \\
\hline Source & \multicolumn{6}{|c|}{$\operatorname{Pr}>F^{\mathrm{z}}$} \\
\hline SPFMV-RC & 0.6322 & 0.0974 & 0.3022 & 0.6268 & 0.3325 & 0.4514 \\
\hline SPVG & 0.0251 & 0.2993 & 0.2853 & 0.4586 & 0.2042 & 0.8415 \\
\hline SPLCV & 0.0460 & 0.3499 & 0.0137 & 0.7149 & 0.0229 & $<0.0001$ \\
\hline SPVG $\times$ SPFMV-RC & 0.6062 & 0.9595 & 0.3854 & 0.7016 & 0.1922 & 0.0127 \\
\hline SPLCV $\times$ SPFMV-RC & 0.8430 & 0.9836 & 0.5277 & 0.3135 & 0.1289 & 0.0861 \\
\hline Block & 0.4171 & 0.3038 & 0.2697 & 0.3243 & 0.0679 & 0.0076 \\
\hline
\end{tabular}

${ }^{y}$ Means followed by * are significantly different from the VT control by Tukey's Studentized Range Test $(\alpha=0.05)$.

${ }^{z}$ Type I probability to exceed $F$ determine by Proc GLM in SAS (ver. 9.0; SAS Institute, Cary, NC).

Table 5. Total yields of Beauregard sweetpotato grown at two planting dates in each of 3 years from virus-tested (VT) plants compared with VT plants graft inoculated with either isolate 95-2 of a russet crack strain of Sweet potato feathery mottle virus (SPFMV-RC), isolate LSU-1 of Sweet potato virus $G$ (SPVG), or isolate LSU-5 of Ipomoea vein mosaic virus (IVMV)

\begin{tabular}{|c|c|c|c|c|c|c|}
\hline \multirow[b]{2}{*}{ Treatment } & \multicolumn{6}{|c|}{ Total yield (metric tons/ha) } \\
\hline & 2001-1 & 2001-2 & 2002-1 & 2002-2 & 2003-1 & 2003-2 \\
\hline VT & 17.5 & 23.6 & 18.8 & 16.6 & 23.7 & 26.6 \\
\hline SPFMV-RC & 18.8 & 23.4 & 16.7 & 16.5 & 29.8 & 17.5 \\
\hline SPVG & 19.0 & 27.6 & 14.4 & 19.0 & 22.7 & 20.9 \\
\hline IVMV & 14.0 & 18.8 & 17.4 & 17.2 & 25.9 & 25.6 \\
\hline SPVG + SPFMV-RC & 20.6 & 23.0 & 14.7 & 15.5 & 24.5 & 15.6 \\
\hline IVMV + SPFMV-RC & 15.0 & 23.0 & 16.0 & 14.6 & 21.9 & 26.8 \\
\hline SPVG + IVMV & NT & NT & NT & NT & 21.9 & 25.4 \\
\hline $\begin{array}{l}\text { SPVG + IVMV + } \\
\text { SPFMV-RC }\end{array}$ & 11.9 & 20.4 & 15.0 & 18.0 & 20.7 & 22.0 \\
\hline Source & \multicolumn{6}{|c|}{$\operatorname{Pr}>F^{\mathrm{z}}$} \\
\hline SPFMV-RC & 0.9274 & 0.6195 & 0.2955 & 0.3103 & 0.6871 & 0.0750 \\
\hline SPVG & 0.6805 & 0.3778 & 0.0553 & 0.2700 & 0.1038 & 0.1704 \\
\hline IVMV & 0.0248 & 0.0824 & 0.7947 & 0.8547 & 0.1392 & 0.0413 \\
\hline SPFMV-RC $\times$ SPVG & 0.8008 & 0.1076 & 0.3332 & 0.6959 & 0.8388 & 0.9171 \\
\hline SPFMV-RC $\times$ IVMV & 0.5940 & 0.4399 & 0.6543 & 0.8978 & 0.0639 & 0.1879 \\
\hline IVMV × SPVG & $\ldots$ & $\ldots$ & $\ldots$ & $\ldots$ & 0.8580 & 0.7693 \\
\hline $\begin{array}{l}\text { SPFMV-RC } \times \\
\text { SPVG } \times \text { IVMV }\end{array}$ & $\cdots$ & $\cdots$ & $\ldots$ & $\ldots$ & 0.3134 & 0.3523 \\
\hline Rep & 0.1716 & 0.1548 & 0.1157 & 0.8969 & 0.2355 & 0.4465 \\
\hline
\end{tabular}

${ }^{\mathrm{z}}$ Type I probability to exceed $F$ as determined using Proc GLM in SAS (ver. 9.0; SAS Institute, Cary, NC).

plain. Infection with SPLCV also resulted in production of storage roots with darker periderm color and, in some cases, longitudinal grooves, giving the roots a less desirable dark, loby appearance not normally observed in commercially grown sweetpotato. There is very little information available on the mechanisms by which viruses affect sweetpotato yields, even for those viruses that induce obvious symptoms. Njeru et al. (29) suggested that single infections with SPFMV or SPCSV might reduce assimilate translocation from leaves to storage roots, which also might explain how a phloeminfecting virus such as SPLCV might reduce yield without inducing symptoms on foliage (20). The effects of SPLCV illustrate the danger in using "symptomless" plants in studies of the effects of sweetpotato viruses, because there may be substantial yield effects even in the absence of symptoms.

Single infections of the three potyviruses used in this study, SPFMV-RC, SPVG, and IVMV, had little effect on yield or quality of Beauregard sweetpotato. Yields of singly infected plants were not significantly different from the VT control in any year for total yield or yield of the premium US\#1 grade of sweetpotato. Over all tests in which they were included, yields of plants coinfected with SPFMVRC and SPVG, or SPFMV-RC, SPVG, and IVMV were about 18 and $14 \%$ less than the VT controls, respectively, but the differences between these treatments and the VT control were significant in only 1 of 4 years.

Periderm color can be affected by a number of environmental variables, especially soil moisture. Overall, it appeared that roots from plants infected with combinations of potyviruses often had a lighter, tanner skin than the rosy VT controls and had lower Hunter a and greater Hunter L values, whereas plants from single infections generally appeared similar to the VT but, in some tests, had lower Hunter a values than the VT. These results are similar to those of Carroll et al. (7) and the periderm color of multiply infected roots commonly is seen in commercially grown sweetpotato.

In 2002, a very low incidence of russet crack occurred on roots from plants infected with SPFMV + SPVG + IVMV. This was not observed in three other years in which this treatment was evaluated and has not been observed on roots from plants infected with these viruses grown in the greenhouse. It is possible that expression of russet crack symptoms on Beauregard requires unknown environmental conditions or that another agent infected these plants in the field in 2002. In another study on the effect of SPFMV on quality factors, Walter and Moyer (34) found that SPFMV did not significantly affect sensory properties of sweetpotato. 
Sweetpotato is a crop for which yield variable, being quite sensitive to environmental fluctuations from year to year, field to field, and even within the same field $(2,4,12,19,28)$. This may explain the significant replication effect in two tests (Tables 1, 3, and 4). It also is possible that potyviruses affect yield of Beauregard sweetpotato but that the effect is too subtle and quality of storage roots is particularly

to demonstrate on an experimental scale, or that other strains of the potyviruses might have a greater effect than the strains selected in this study. However, one additional strain each of SPVG and IVMV and three additional strains of SPFMV were evaluated for 1 year in field tests and did not differ from the strains used in this study (data not presented). Furthermore, other studies also have indicated that

Table 6. Periderm and internal flesh color of Beauregard sweetpotato storage roots grown from either virus-tested (VT) plants or VT plants graft inoculated with isolate 95-2 of the russet crack strain of Sweet potato feathery mottle virus (SPFMV-RC), isolate LSU-1 of Sweet potato virus G (SPVG), or isolate LSU-5 of Ipomoea vein mosaic virus (IVMV) in the first planting, 2003

\begin{tabular}{|c|c|c|c|c|c|c|}
\hline \multirow[b]{2}{*}{ Virus treatment } & \multicolumn{3}{|c|}{ Periderm color measurements $^{\mathrm{y}}$} & \multicolumn{3}{|c|}{ Flesh color measurements $^{y}$} \\
\hline & Hunter L & Hunter a & Hunter b & Hunter L & Hunter a & Hunter b \\
\hline VT & $51.25 \mathrm{a}$ & $16.77 \mathrm{a}$ & 14.78 & $62.80 \mathrm{ab}$ & 26.76 & $24.00 \mathrm{ab}$ \\
\hline SPFMV-RC & $54.43 \mathrm{~b}$ & $14.84 \mathrm{ab}$ & 14.64 & $64.09 \mathrm{a}$ & 26.96 & $24.39 \mathrm{a}$ \\
\hline SPVG & $51.22 \mathrm{a}$ & $15.56 \mathrm{ab}$ & 14.17 & $63.11 \mathrm{ab}$ & 27.88 & $24.65 \mathrm{a}$ \\
\hline IVMV & $50.49 \mathrm{a}$ & $15.82 \mathrm{ab}$ & 14.06 & $63.28 \mathrm{ab}$ & 27.31 & $24.34 \mathrm{a}$ \\
\hline SPVG + SPFMV-RC & $51.83 \mathrm{ab}$ & $15.41 \mathrm{ab}$ & 14.17 & $63.30 \mathrm{a}$ & 26.54 & $23.87 a b$ \\
\hline SPVG + IVMV & $51.40 \mathrm{ab}$ & $15.51 \mathrm{ab}$ & 14.03 & $63.24 \mathrm{ab}$ & 26.83 & $24.01 \mathrm{ab}$ \\
\hline IVMV + SPFMV-RC & $52.90 \mathrm{ab}$ & $15.09 \mathrm{ab}$ & 14.84 & $61.74 a b$ & 25.87 & $23.10 \mathrm{ab}$ \\
\hline $\begin{array}{l}\text { SPVG + IVMV + } \\
\text { SFMV-RC }\end{array}$ & $52.03 \mathrm{ab}$ & $14.28 \mathrm{~b}$ & 14.56 & $60.44 \mathrm{~b}$ & 25.06 & $22.55 \mathrm{~b}$ \\
\hline Source & \multicolumn{6}{|c|}{$\operatorname{Pr}>F^{\mathbf{z}}$} \\
\hline SPFMV-RC & 0.0004 & 0.0116 & 0.2557 & 0.1126 & 0.0312 & 0.0067 \\
\hline SPVG & 0.1353 & 0.2449 & 0.1767 & 0.3063 & 0.7564 & 0.4780 \\
\hline IVMV & 0.2692 & 0.2165 & 0.7978 & 0.0136 & 0.1222 & 0.0102 \\
\hline SPVG $\times$ IVMV & 0.1248 & 0.7490 & 0.4553 & 0.6315 & 0.3072 & 0.3478 \\
\hline SPVG $\times$ SPFMV $-R C$ & 0.0153 & 0.3950 & 0.9143 & 0.1882 & 0.3343 & 0.1966 \\
\hline IVMV $\times$ SPFMV $-R C$ & 0.6585 & 0.9384 & 0.1597 & 0.0024 & 0.2864 & 0.0373 \\
\hline $\begin{array}{l}\text { SPVG } \times \text { IVMV } \times \\
\text { SPFMV-RC }\end{array}$ & 0.6440 & 0.1354 & 0.7068 & 0.9244 & 0.5322 & 0.3782 \\
\hline Rep & 0.5746 & 0.6786 & 0.1700 & 0.2947 & 0.8164 & 0.5804 \\
\hline
\end{tabular}

${ }^{y}$ Means in the same column followed by a common letter are not significantly different by Tukey's Studentized Range Test $(\alpha=0.05)$.

${ }^{\mathrm{z}}$ Type I probability to exceed F as determined using Proc GLM in SAS (ver. 9.0; SAS Institute, Cary, NC).

Table 7. Periderm and internal flesh color of Beauregard sweetpotato storage roots grown from either virus-tested (VT) plants or VT plants graft inoculated with isolate 95-2 of the russet crack strain of Sweet potato feathery mottle virus (SPFMV-RC), isolate LSU-1 of Sweet potato virus G (SPVG), or isolate LSU-5 of Ipomoea vein mosaic virus (IVMV) in the second planting, 2003

\begin{tabular}{|c|c|c|c|c|c|c|}
\hline \multirow[b]{2}{*}{ Virus treatment } & \multicolumn{3}{|c|}{ Periderm color measurements ${ }^{y}$} & \multicolumn{3}{|c|}{ Flesh color measurements ${ }^{y}$} \\
\hline & Hunter L & Hunter a & Hunter b & Hunter L & Hunter a & Hunter b \\
\hline VT & 48.24 & $15.86 \mathrm{a}$ & 13.16 & 61.99 & 24.69 & $22.92 \mathrm{ab}$ \\
\hline SPFMV-RC & 51.26 & $13.50 \mathrm{~b}$ & 13.53 & 63.32 & 23.95 & $23.38 \mathrm{ab}$ \\
\hline SPVG & 48.68 & $13.89 \mathrm{~b}$ & 12.31 & 64.40 & 23.69 & $23.47 \mathrm{ab}$ \\
\hline IVMV & 50.43 & $14.00 \mathrm{~b}$ & 12.41 & 63.83 & 26.07 & $24.36 \mathrm{a}$ \\
\hline SPVG + SPFMV-RC & 49.33 & $12.86 \mathrm{~b}$ & 13.08 & 62.99 & 22.53 & $22.46 \mathrm{~b}$ \\
\hline SPVG + IVMV & 49.23 & $14.37 \mathrm{ab}$ & 12.29 & 63.26 & 22.08 & $22.38 \mathrm{~b}$ \\
\hline IVMV + SPFMV-RC & 50.87 & $13.67 \mathrm{~b}$ & 13.51 & 63.15 & 22.95 & $22.28 \mathrm{~b}$ \\
\hline $\begin{array}{l}\text { SPVG + IVMV + } \\
\text { SFMV-RC }\end{array}$ & 50.80 & $13.11 \mathrm{~b}$ & 13.45 & 63.54 & 22.18 & $22.19 b$ \\
\hline Source & \multicolumn{6}{|c|}{$\operatorname{Pr}>F^{\mathbf{z}}$} \\
\hline SPFMV-RC & 0.0203 & 0.0001 & 0.0052 & 0.8157 & 0.0605 & 0.0210 \\
\hline SPVG & 0.2460 & 0.0166 & 0.2010 & 0.3609 & 0.0079 & 0.0424 \\
\hline IVMV & 0.1097 & 0.3913 & 0.7186 & 0.6041 & 0.5372 & 0.3870 \\
\hline SPVG × IVMV & 0.9269 & 0.0368 & 0.3272 & 0.2820 & 0.3600 & 0.1498 \\
\hline SPVG $\times$ SPFMV $-R C$ & 0.5961 & 0.7199 & 0.6817 & 0.3904 & 0.2755 & 0.7261 \\
\hline IVMV $\times$ SPFMV $-R C$ & 0.4787 & 0.1133 & 0.3257 & 0.8757 & 0.6605 & 0.1464 \\
\hline $\begin{array}{l}\text { SPVG } \times \text { IVMV } \times \\
\text { SPFMV-RC }\end{array}$ & 0.1406 & 0.0490 & 0.7614 & 0.0826 & 0.1600 & 0.0068 \\
\hline Rep & 0.1673 & $<0.0001$ & 0.5590 & 0.0027 & 0.8492 & 0.8832 \\
\hline
\end{tabular}

${ }^{y}$ Means in the same column followed by a common letter are not significantly different by Tukey's Studentized Range Test $(\alpha=0.05)$.

${ }^{\mathrm{z}}$ Type I probability to exceed $F$ as determined using Proc GLM in SAS (ver. 9.0; SAS Institute, Cary, $\mathrm{NC})$.
SPFMV did not affect yield (14,23,29). It also is possible that reinfection of VT plants could reduce yields in the control; however, in the present study, reinfection was determined to be low in most years $($ mean $=18 \%)$ and yields of the VT plots were considered to be relatively high.

The results of this study provide evidence that the commonly occurring potyviruses SPFMV, SPVG, and IVMV, alone and in combination, do not reproduce the yield effects observed in this study with naturally infected plants as inocula or the yield effects observed by Carroll et al. (7) or Bryan et al. (5). SPLCV caused measurable reductions in yield but did not reproduce the magnitude of yield reduction seen with the natural sources. Furthermore, SPLCV has not been found to occur commonly in commercially grown sweetpotato. Although a number of other viruses have been reported from sweetpotato from other countries (32), surveys of U.S. sweetpotato using NCM-ELISA assays have not detected Sweet potato mild mottle virus, Sweet potato latent virus, Sweet potato chlorotic flecks virus, Sweet potato mild speckling virus, Sweet potato caulimo-like virus, or Sweet potato chlorotic stunt virus (C. A. Clark and $\mathrm{M}$. W. Hoy, unpublished data). Although this does not conclusively demonstrate the absence of these viruses, it does suggest that none of them are common. Two other systemic pathogens occur commonly on sweetpotato, the chlorotic leaf distortion (CLD) pathogen, Fusarium denticulatum (11), and the bacterial root and stem rot pathogen, Erwinia chrysanthemi (9). In a previous study, CLD did not affect yield of sweetpotato, regardless of symptom severity (21). It is possible that E. chrysanthemi contributes to yield reduction; however, neither stem rot nor soft rot of storage roots was observed in plants graft inoculated with the natural sources. Thus, research is warranted into the possibility that other as yet unidentified viruses are contributing to yield reduction or russet crack etiology in sweetpotato in the United States.

\section{ACKNOWLEDGMENTS}

Support and partial funding was provided by the Louisiana Sweet Potato Advertising and Development Commission. We thank L. McKoin and T. Raiford for their valuable assistance.

\section{LITERATURE CITED}

1. Aritua, V., Olanya, O. M., El-Bedewy, R., and Ewell, P. T. 2000. Yield and reaction of nonindigenous sweetpotato clones to sweetpotato virus disease in Uganda. Pages 48-54 in: Proc. Int. Workshop Sweet Potato Cultivar Decline Study. Y. Nakazawa and K. Ishiguro, eds. Miyakonojo, Japan.

2. Bacusmo, J. L., Collins, W. W., and Jones, A. 1988. Comparison of methods of determining stability and adaptation of sweetpotato. Theor. Appl. Genet. 75:492-497.

3. Borders, H. I., and Ratcliff, T. J. 1954. A mosaic of sweetpotato in plant beds and fields in Georgia. Plant Dis. Rep. 38:6-9. 
4. Bryan, A. D., Pesic-van Esbroeck, Z., Schultheis, J. R., Pecota, K. V., Swallow, W. H., and Yencho, G. C. 2003. Cultivar decline in sweetpotato: I. Impact of micropropagation on yield, storage root quality, and virus incidence in 'Beauregard'. J. Am. Soc. Hortic. Sci. 128:846-855.

5. Bryan, A. D., Schultheis, J. R., Pesic-van Esbroeck, Z., and Yencho, G. C. 2003. Cultivar decline in sweetpotato: II. Impact of virus infection on yield and storage root quality in 'Beauregard' and 'Hernandez'. J. Am. Soc. Hortic. Sci. 128:856-863.

6. Carroll, H. W., Villordon, A. Q., Clark, C. A., La Bonte, D. R., and Hoy, M. W. 2003. Studies on Beauregard sweetpotato clones naturally infected with viruses. Int. J. Pest Manage. 50:101-106.

7. Chung, M-L., Liao, C-H., and Li, L. 1981. Effect of virus infection on the yield and quality of sweetpotatoes. Plant Prot. Bull. Taiwan 23:137-141.

8. Clark, C. A., Hoy, M. W., Valverde, R. A., La Bonte, D. R., and Cannon, J. M. 2002. Effects of viruses on sweetpotatoes in Louisiana, USA. Pages 238-241 in: Potential of Root Crops for Food and Industrial Resources, Twelfth Symp. Int. Soc. Trop. Root Crops. M. Nakatani and K. Komaki, eds. Tsukuba, Japan.

9. Clark, C. A., and Moyer, J. W. 1988. Compendium of Sweet Potato Diseases. American Phytopathological Society Press, St. Paul, MN.

10. Clark, C. A., Valverde, R. A., Fuentes, S., Salazar, L. F., and Moyer, J. W. 2002. Research for improved management of sweetpotato pests and diseases: Cultivar decline. Pages 103-112 in: Proc. 1st Int. Conf. Sweetpotato, Food and Health for the Future, Lima, Peru. T. Ames, ed. Acta Hortic. 583.

11. Clark, C. A., Valverde, R. A., Wilder-Ayers, J. A., and Nelson, P. E. 1990. Fusarium lateritium, causal agent of sweetpotato chlorotic leaf distortion. Phytopathology 80:741-744.

12. Collins, W. W., Wilson, L. G., Arrendell, S., and Dickey, L. F. 1987. Genotype $\times$ environment interactions in sweetpotato yield and quality factors. J. Am. Soc. Hortic. Sci. 112:579-583

13. Girardeau, J. H., and Ratcliffe, T. J. 1963. Apparent eradication of mosaic of sweetpota- toes in Georgia aided by the disappearance of the insect vector. Plant Dis. Rep. 47:791-792.

14. Gutierrez, D. L., Fuentes, S., and Salazar, L. 2003. Sweetpotato virus disease (SPVD): distribution, incidence, and effect on sweetpotato yield in Peru. Plant Dis. 87:297-302.

15. Hahn, S. K. 1979. Effects of viruses (SPVD) on growth and yield of sweetpotato. Exp. Agric. $15: 253-256$.

16. Hunter, R. S. 1958. Photoelectric color difference meter. J. Opt. Soc. Am. 48:985-995.

17. Jester, W. R., Averre, C. W., and Schultheis, J. R. 1994. Russet crack-like symptoms in Beauregard sweetpotato reduced by virus indexing and micropropagation. (Abstr.) HortScience 29:727.

18. Kantack, E. J., and Martin, W. J. 1958. Effect of internal cork on yield and grade of sweetpotato roots. Phytopathology 48:521-522.

19. Kanua, M. B., and Floyd, C. N. 1988. Sweetpotato genotype $\times$ environment interactions in the highlands of Papua New Guinea. Trop. Agric. 65:9-15.

20. Kays, S. J. 1985. The physiology of yield in the sweetpotato. Pages 79-132 in: Sweet Potato Products: A Natural Resource for the Tropics. J. C. Bouwkamp, ed. CRC Press, Boca Raton, FL.

21. Kim, B. K., La Bonte, D. R., and Clark, C. A. 1996. Studies on sweetpotato with chlorotic leaf distortion, caused by Fusarium lateritium. Int. J. Pest Manage. 42:67-70.

22. Lotrakul, P., Valverde, R. A., Clark, C. A., Sim, J., and De La Torre, R. 1998. Detection of a geminivirus infecting sweetpotato in the United States. Plant Dis. 82:1253-1257.

23. Milgram, M., Cohen, J., and Loebenstein, G. 1996. Effects of sweetpotato feathery mottle virus and sweetpotato sunken vein virus on sweetpotato yields and rates of reinfection of virus-free planting material in Israel. Phytoparasitica 24:189-193.

24. Moyer, J. W., and Kennedy, G. G. 1978. Purification and properties of sweetpotato feathery mottle virus. Phytopathology 68:998-1004.

25. Mukiibi, J. 1976. Effect of mosaic on the yield of sweetpotatoes in Uganda. Pages 169-170 in: Proc. 4th Symp. Int. Soc. Trop. Root Crops. J. Cock, R. MacIntyre, and M. Graham, eds. Int. Dev. Res. Centre, Ottawa, Canada.

26. Ngeve, J. M. 1990. Yield stability and yield depression in sweetpotato cultivars susceptible to the sweetpotato virus disease. J. Hortic. Sci. 65:225-230.

27. Ngeve, J. M., and Bouwkamp, J. C. 1991. Effects of sweetpotato virus disease (SPVD) on the yield of sweetpotato genotypes in Cameroon. Exp. Agric. 27:221-225.

28. Ngeve, J. M., and Bouwkamp, J. C. 1993. Comparison of statistical methods to assess yield stability in sweetpotato. J. Am. Soc. Hortic. Sci. 118:304-310.

29. Njeru, R. W., Mburu, M. W. K., Cheramgoi, E., Gibson, R. W., Kiburi, Z. M., Obudho, E. and Yobera, D. 2004. Studies on the physiological effects of viruses on sweetpotato yield in Kenya. Ann. Appl. Biol. 145:71-76.

30. Olivero, C. A., and Oropeza, T. 1985. Efectos del virus del moteado plumoso (FMV) sobre el rendimiento y otros parámetros agronómicos del cultivo de la batata (Ipomoea batatas (L.) Lam.). Agron. Trop. 35:167-172.

31. Pio-Ribeiro, G., Winter, S., Jarret, R. L., Demski, J. W., and Hamilton, R. I. 1996. Detection of sweetpotato virus disease-associated closterovirus in a sweetpotato accession in the United States. Plant Dis. 80:551-554.

32. Salazar, L. F., and Fuentes, S. 2000. Current knowledge on the major virus diseases of sweetpotatoes. Pages 14-19 in: Int. Workshop Sweetpotato Cultivar Decline Study. Y. Nakazawa and K. Ishiguru, eds. Miyakonojo, Japan.

33. Souto, E. R., Sim, J. Chen, J., Valverde, R. A., and Clark, C. A. 2003. Properties of strains of Sweet potato feathery mottle virus and two newly recognized potyviruses infecting sweetpotato in the United States. Plant Dis. 87:12261232.

34. Walter, W. M., and Moyer, J. W. 1987. Effect of feathery mottle virus infection on sweetpotato sensory properties. J. Food Sci. 52:12981301

35. Wisler, G. C., Duffus, J. E., Liu, H.-Y., and Li, R. H. 1998. Ecology and epidemiology of whitefly-transmitted closteroviruses. Plant Dis. 82:270-280

36. Xing, J.-Y., Sun, A.-G., Hu, L.-Y., and Yang, Y.-J. 1999. Continuous cropping of virus free sweetpotato, infection with viruses and its effect on yield. Jiangsu Agric. Sci. 1999(6):4748 